\title{
Phytoremediation of some heavy metals using Prosopis juli flora and Conocarpus lancifolius- Soil analysis
}

\author{
Ghalia Saleem Aljeddani
}

Faculty of Science, University of Jeddah, PO Box 80327, Jeddah 21589, Saudi Arabia

\author{
Corresponding author: drghalia2012@gmail.com
}

\begin{abstract}
Environmental pollution is causing damage to the flora and fauna, resulting in a number of negative impacts on the environment. The present study aims towards evaluation of soil heavy metals (chromium, lead, and nickel) from different locations of Jeddah using leaves of two plant species. Two naturally grown plant species, Prosopis juli flora and Conocarpus lancifolius were collected from four different sites. The soil samples were collected near the factories, main roads, and branch roads in Jeddah. The soil samples were dried and sieved through a $2 \mathrm{~mm}$ plastic sieve to remove large gravel-sized materials. Soil texture, $\mathrm{pH}$, and EC evaluation were conducted. The amount of $\mathrm{Cr}, \mathrm{Pb}$, and $\mathrm{Ni}$ was determined using Atomic Absorption Spectrophotometer Model Inductivity coupled plasma emission spectrometer ICP (PARKIN ELEMER). SPSS, ANOVA, and Post-Hoc Test were used to analyze the data. The results showed that the amount of heavy metal in the soil of Prosopis juli flora were between 0.74-54.0 $\mu \mathrm{g} / \mathrm{g} \mathrm{D.wt}$. for $\mathrm{Cr}, 0.31-4.64 \mu \mathrm{g} / \mathrm{g}$

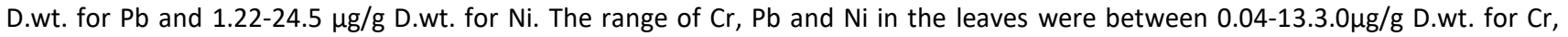

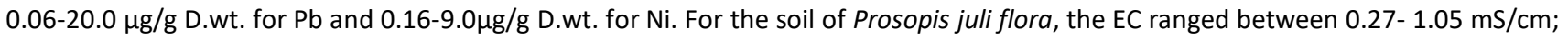
whereas, $\mathrm{pH}$ ranged from $7.29-7.55$ and $78.5-96.5 \%$ for sand, $1.0-16.5 \%$ for silt, and $1.0-6.0$ for clay. There was a significant correlation between the soil textures, clay, and silt at selected sites. Phytoremediation is an effective strategy to overcome the effects of heavy metals including $\mathrm{Cr}, \mathrm{Pb}$, and $\mathrm{Ni}$ that are being absorbed in plants.
\end{abstract}

Keywords: Conocarpus Lancifolius, Hazard, Heavy Metals, Prosopis Juliflora, Soil Analysis.

Introduction

The high release of heavy metals into surface, ground water, soils and the biosphere is observed through human activities such as industrial production, agriculture, mining, and transportation (Nazir et al., 2015). The probability of food contamination through the soil root interface increases the concern towards the accumulation of heavy metals in crop plants (Nazir et al., 2015). Heavy metals are found in the soil and geology of earth. These heavy metals can significantly influence the physiological and anatomical feature of plants such as stomata density of the leaves (Gomes et al., 2011). On the other hand, anthropogenic activities result in an increase in the concentration of such elements, which in turn, causes dangerous side-effects to flora and fauna.

The heavy metals including Chromium ( $\mathrm{Cr}$ ), Nickel (Ni), and Lead $(\mathrm{Pb})$ are not essential for plant growth; however, they are taken up and accumulated inside the plant tissues in toxic forms. An important role is played by the heavy metal concentration in the soil to control the metal bioavailability to the plants. The concentration of heavy metals in the soils is likely to increase over the permissible limit if they have been irrigated with contaminated water since a long time. However, the factor affecting the ability of plants to take up heavy metals include; the type of soil, type of plant species and growth stage of the particular plant (Khan et al., 2011).

Plant species, such as Bruguiera sexangula and Zygophyllum $\mathrm{sp}$. were also found to be subjected to the accumulation of heavy metals (Gupta and Chakrabarti, 2013; Morsy et al., 2012). Chromium ( $\mathrm{Cr}$ ) is widely used for chromate plating and stainless steel. Wood preservatives and pigments are highly prepared by $\mathrm{Cr}$ (both +3 and +6 ) in the chemical industries. Moreover, green tints, for various purposes are also prepared by the same element. Cr compounds are especially utilized in large amounts for leather tanning. Additionally, the metal is also used in bulk quantity in paper manufacturing (KabataPendias, 2010). Nickel (Ni) is further released into the soil through various sources during anthropogenic actions (Alt, 2000). Furthermore, Lead (Pb) is mainly and extensively used in lead-acid batteries, cables, chemicals, and for several other purposes. On the other hand, $\mathrm{Pb}$-containing paints in soil are found in garden or home areas as other sources of lead 
(Kabata-Pendias, 2010). Therefore, the present study aims to determine the amount of pollution by heavy metals, such as chromium ( $\mathrm{Cr})$, lead $(\mathrm{Pb})$, and nickel (Ni) pollutants in soil and in leaves of two plant species (Prosopis juli flora and Conocarpus lancifolius) growing naturally in the contaminated soils in Jeddah, Saudi Arabia.

\section{Results and Discussion}

\section{Soil analysis of heavy metals ( $\mathrm{Cr}, \mathrm{Pb}$ and $\mathrm{Ni}$ ) in leaves of Prosopis juli flora}

The data presented in Table 1. reveals the content of heavy metals $(\mathrm{Cr}, \mathrm{Pb}$ and $\mathrm{Ni})$ in the soil and in Prosopis juli flora leaves. The ranges of heavy metal in the soil (under natural

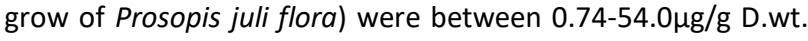
for $\mathrm{Cr}, 0.31-4.64 \mu \mathrm{g} / \mathrm{g}$ D.wt. for Pb and 1.22-24.5 $\mu \mathrm{g} / \mathrm{g}$ D.wt. for $\mathrm{Ni}$. The results for polluted sites were higher than unpolluted (control) but lower than normal amount for heavy metal in soil for $\mathrm{Cr}, \mathrm{Pb}$ are $100 \mu \mathrm{g} / \mathrm{g}$ and for $\mathrm{Ni}$ is $50 \mu \mathrm{g} / \mathrm{g}$ (Chiroma et al., 2014).

The quantity of heavy metals in plant shows that the range of $\mathrm{Cr}, \mathrm{Pb}$ and $\mathrm{Ni}$ in the leaves were between 0.04-13.3.0 $\mu \mathrm{g} / \mathrm{g}$ D.wt. for $\mathrm{Cr}, 0.06-20.0 \mu \mathrm{g} / \mathrm{g}$ D.wt. for $\mathrm{Pb}$ and $0.16-9.0 \mu \mathrm{g} / \mathrm{g}$ D.wt. for $\mathrm{Ni}$ (Table 1). The results for polluted sites were higher than non-polluted sites. Furthermore, higher than normal amount of heavy metals $(\mathrm{Cr}, \mathrm{Ni}$ are $0.1-5 \mu \mathrm{g} / \mathrm{g}$ and $\mathrm{Pb} 5-10$ $\mu \mathrm{g} / \mathrm{g}$ ) in plant species were detected (Butkus and Baltrènaite, 2007). The data shown in Table 2 show that the EC for the soil of Prosopis juli flora ranged between $0.27-1.05 \mathrm{mS} / \mathrm{cm}, \mathrm{pH}$ from $7.29-7.55$ and $78.5-96.5 \%$ in sand, $1.0-16.5 \%$ in silt and 1.0-6.0 in clay soils. The results presented significant correlation between the soil textures, clay and silt at selected sites. A previous study has shown that the accumulation of heavy metals on several plant species was due to their capability of accumulating and removing heavy metals (Markert, 1993). Environmental degradation is caused when these metals from the environment accumulate on woody plants (Agbogidi et al., 2013). Hence, there are significant correlations between amount of $\mathrm{Cr}, \mathrm{Pb}$, and $\mathrm{Ni}$ in soil and, $\mathrm{Pb}$ and $\mathrm{Ni}$ in plant. In addition, there was a high significance between $\mathrm{Pb}$ in soil and $\mathrm{Pb}$ in plant as shown in Table 3.

\section{Soil analysis of heavy metals ( $\mathrm{Cr}, \mathrm{Pb}$ and $\mathrm{Ni}$ ) in leaves of Conocarpus lancifolius}

The data shown in Table 4 has elucidated the amount of heavy metals $\mathrm{Cr}, \mathrm{Pb}$, and $\mathrm{Ni}$ in the soil and leaves of Conocarpus lancifolius. The ranges of heavy metal in soil of Conocarpus lancifolius sites are between 1.1-133.3 $\mu \mathrm{g} / \mathrm{g}$ d.wt for $\mathrm{Cr}$, 0.27$128.8 \mu \mathrm{g} / \mathrm{g}$ D.wt. for $\mathrm{Pb}$ and 9.4-36.2 $\mu \mathrm{g} / \mathrm{g}$ D.wt. for Ni. The contaminations were higher for polluted sites as compared to the low polluted sites. However, lower than normal (standard) amount for heavy metal in the soil was observed for $\mathrm{Cr}, \mathrm{Pb}$ are $100 \mu \mathrm{g} / \mathrm{g}$ and for $\mathrm{Ni}$ is $50 \mu \mathrm{g} / \mathrm{g}$ (Chiroma et al., 2014). Moreover, except the first site (PR) near Petroleum Refinery, the soil had more amount of lead than the leaves of Conocarpus lancifolius and more than normal (standard) amount for heavy metal in soil ( $\mathrm{Pb} 100 \mu \mathrm{g} / \mathrm{g}$ ). Pb concentration was found to be more in the leaves compared to its presence in the park locations. The roots were found to contain more heavy metals as compared to leaves. Thus, air pollution can be considered as another reason for metal pollution in trees. Heavy metals levels in plants have increased noticeably due to traffic pollution especially from consumption of leaded petrol and exhaust fire (Aslam et al., 2012).

The amount of these metals in the samples of plants (as shown in the Table 4), especially in leaves, was between $9.2-30.7 .0$ $\mu \mathrm{g} / \mathrm{g}$ D.wt. for $\mathrm{Cr}, 6.0$-57.4 $\mu \mathrm{g} / \mathrm{g}$ D.wt. for $\mathrm{Pb}$ and 0.6.5-19.6 $\mu \mathrm{g} / \mathrm{g}$ D.wt. for Ni. The results for polluted sites were found to be higher than the results obtained for unpolluted sites. Moreover, the normal value of $\mathrm{Cr}, \mathrm{Ni}$ were $(0.1-5) \mathrm{\mu g} / \mathrm{g}$ in plants (Butkus \& Baltrènaite, 2007) and higher than standard for $\mathrm{Pb}(5-10) \mu \mathrm{g} / \mathrm{g}$. There was a significant correlation between sand (\%) and silt (\%) in soil and $\mathrm{Pb}$ in the leaves of Conocarpus lancifolius and $\mathrm{Ni}$ in plant. Table 5 has shown that EC for the soil of Conocarpus lancifolius ranged between 0.35-1.44 $\mathrm{mS} / \mathrm{cm}, \mathrm{pH}$ from $6.79-7.7$ and $77.0-94.5 \%$ for sand, $1.0-20.5 \%$ for silt, and $2.0-4.54 \%$ for clay. Results presented significant correlation in $\mathrm{EC}, \mathrm{pH}$, sand \%, and silt \% in selected sites.

A high significant difference between $\mathrm{Ni}$ in soil and $\mathrm{Pb}$ in plant was shown in Table 6 . $\mathrm{Ni}, \mathrm{Cu}, \mathrm{Zn}$, and $\mathrm{Cd}$ are released from industrial metallurgical processes in high percentages. On the other hand, $\mathrm{Ni}, \mathrm{Cd}, \mathrm{Zn}$, and $\mathrm{Pb}$ might be present in high quantities in exhaust production from gasoline (Samara and Voutsa, 2005). The uptake of metals from the soil depends on different factors, such as their soluble content, soil $\mathrm{pH}$, plant species, fertilizers, and soil type (Naser et al., 2011). Comparison of lead amount in Conocarpus lancifolius and Prosopis juli flora in King Faisal road proved that Conocarpus lancifolius accumulates led more than Prosopis juli flora. The accumulator collects high amount of metals in the plants and low metal concentration in the soil (Aslam et. al., 2012). Phytoremediation is a promising technology and a sub-type of bioremediation, which is firmly applied to the use of green plants for the remediation of organic as well as inorganic contaminants from polluted soil, water or air (Salt et al., 1998). It was found that Ziziphus tree leaves, were extensively subjected to hazardous metals due to industrial actions, which resulted in the growth of micro-nutrients on the surface of tree leaves. Paints, paper, and chemical industries were found as the heaviest metal releasing entities as suggested by the presence of $\mathrm{Cd}, \mathrm{Cr}, \mathrm{Ni}$, and $\mathrm{Pb}$ concentrations on leaves of the trees near such industries (Shaheen et al., 2014). Metal accumulation on plants depends on different factors, such as uniqueness of metals, genetics, distance from pollution sources, and climatic factors such as soil properties, wind direction, and intake from soil (Osma, 2013).

\section{Materials and methods}

\section{Collection of soil and leaves}

All sites were selected in Jeddah according to traffic density and industrial activities. Four sites were chosen from different location in Jeddah. Samples were taken from areas near factories, main roads and branch roads and samples were collected during March 2015 (Figure 1). 
Table 1. The amount of heavy elements mean \pm SD in the leaves of Prosopis juli flora sites $(n=2) *$ : Statistically significant at $p \leq 0.05$ and LSD (5\%)

\begin{tabular}{|c|c|c|c|c|c|c|}
\hline \multirow[t]{2}{*}{ Site } & \multicolumn{3}{|c|}{ Soil (mg/g d.wt) } & \multicolumn{3}{|c|}{ Plant (Mg/g d.wt) } \\
\hline & $\mathrm{Cr}$ & $\mathrm{Pb}$ & $\mathrm{Ni}$ & $\mathrm{Cr}$ & $\mathrm{Pb}$ & $\mathrm{Ni}$ \\
\hline $\mathrm{IF}$ & $54.0^{\mathrm{a}} \pm 12.8$ & $0.43^{b} \pm 0.06$ & $24.5^{\mathrm{a}} \pm 0.09$ & $9.1^{\mathrm{ab}} \pm 0.71$ & $8.6^{\mathrm{abc}} \pm 1.7$ & $7.2^{\mathrm{a}} \pm 1.41$ \\
\hline FR & $25.9^{b c} \pm 6.6$ & $3.7^{\mathrm{a}} \pm 0.14$ & $12.6^{\mathrm{b}} \pm 1.84$ & $10.9^{\mathrm{a}} \pm 3.8$ & $16.9^{\mathrm{ab}} \pm 10.04$ & $8.8^{a} \pm 0.85$ \\
\hline JMR & $43.1^{\mathrm{ab}} \pm 4.0$ & $4.64^{\mathrm{a}} \pm 1.18$ & $21.6^{\mathrm{ab}} \pm 0.57$ & $13.3^{\mathrm{a}} \pm 7.21$ & $20.0^{\mathrm{a}} \pm 2.26$ & $9.0^{\mathrm{a}} \pm 2.83$ \\
\hline SRB & $41.4^{\mathrm{ab}} \pm 17.9$ & $1.54^{\mathrm{b}} \pm 0.47$ & $19.3^{\mathrm{ab}} \pm 7.64$ & $10.1^{\mathrm{a}} \pm 1.84$ & $6.1^{b c} \pm 0.42$ & $5.8^{\mathrm{a}} \pm 1.41$ \\
\hline $\begin{array}{l}\text { Control } \\
\text { (Non-polluted) }\end{array}$ & $0.74^{c} \pm 0.14$ & $0.31^{\mathrm{b}} \pm 0.37$ & $1.22^{c} \pm 0.04$ & $0.04^{b} \pm 0.04$ & $0.06^{\mathrm{c}} \pm 0.08$ & $0.16^{\mathrm{b}} \pm 0.04$ \\
\hline $\mathrm{F}$ & $7.875^{*}$ & $21.529^{*}$ & $13.904^{*}$ & 3.661 & $6.035^{*}$ & $10.266^{*}$ \\
\hline $\mathrm{P}$ & $0.022^{*}$ & $0.002^{*}$ & $0.006^{*}$ & 0.094 & $0.037^{*}$ & $0.013^{*}$ \\
\hline LSD (5\%) & 26.75 & 1.533 & 9.0542 & 9.6512 & 12.003 & 4.1003 \\
\hline
\end{tabular}

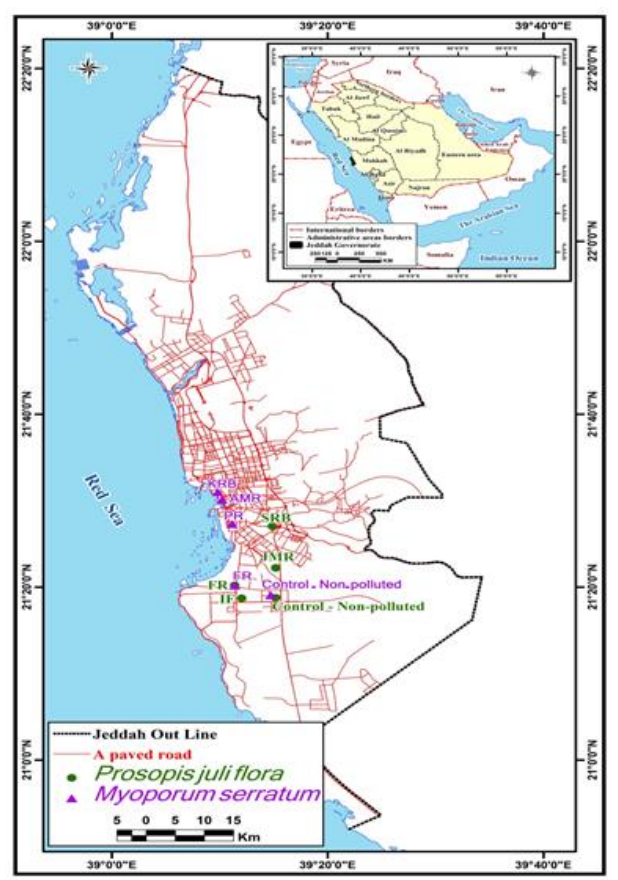

Fig 1. Map of study area Source: Google Earth Pro 2017

Table 2. Ec, $\mathrm{pH}$ and proportions of soil particles to soil sites Prosopis juli floramean $\pm \mathrm{SD}(\mathrm{n}=2)^{*}$ : Statistically significant at $\mathrm{p} \leq 0.05$ and LSD (5\%)

\begin{tabular}{|c|c|c|c|c|c|}
\hline \multirow[t]{2}{*}{ Site } & \multirow[t]{2}{*}{$\mathrm{EC}(\mathrm{mS} / \mathrm{cm})$} & \multirow[t]{2}{*}{$\mathrm{pH}$} & \multicolumn{3}{|c|}{ Soil Texture\% } \\
\hline & & & Sand & Silt & Clay \\
\hline IF & $0.91^{\mathrm{a}} \pm 0.85$ & $7.29^{a} \pm 0.14$ & $82.5^{c d} \pm 3.54$ & $16.5^{a} \pm 3.54$ & $1.0^{b} \pm 0.0$ \\
\hline FR & $0.87^{a} \pm 0.25$ & $7.42^{a} \pm 0.04$ & $91.5^{b} \pm 0.71$ & $3.5^{b c} \pm 0.71$ & $5.0^{\mathrm{a}} \pm 0.0$ \\
\hline JMR & $1.05^{a} \pm 0.47$ & $7.39^{a} \pm 0.35$ & $78.5^{d} \pm 0.71$ & $15.5^{\mathrm{a}} \pm 2.12$ & $6.0^{a} \pm 1.41$ \\
\hline SRB & $0.27^{\mathrm{a}} \pm 0.01$ & $7.55^{a} \pm 0.09$ & $86.5^{c} \pm 2.12$ & $7.5^{b} \pm 2.12$ & $6.0^{a} \pm 0.0$ \\
\hline $\begin{array}{l}\text { Control } \\
\text { (Non-polluted) }\end{array}$ & $0.52^{\mathrm{a}} \pm 0.0$ & $7.47^{a} \pm 0.01$ & $96.5^{a} \pm 0.71$ & $1.0^{c} \pm 0.0$ & $2.5^{b} \pm 0.71$ \\
\hline $\mathrm{F}$ & 1.007 & 0.577 & $27.459^{*}$ & $22.136^{*}$ & $20.200^{*}$ \\
\hline $\mathrm{P}$ & 0.483 & 0.693 & $0.001^{*}$ & $0.002^{*}$ & $0.003^{*}$ \\
\hline LSD (5\%) & 1.153 & 0.4533 & 4.9446 & 5.3921 & 1.8177 \\
\hline
\end{tabular}


Table 3. Correlation among different parameters of Prosopis juliflorasite. $r$ : Pearson coefficient *: Statistically significant at $p \leq 0.05$ ( $n=$ 8).

\begin{tabular}{|c|c|c|c|c|c|c|}
\hline \multirow[t]{3}{*}{ Parameter } & \multicolumn{6}{|c|}{ Plant (Mg/g d.wt) } \\
\hline & \multicolumn{2}{|c|}{$\mathrm{Cr}$} & \multicolumn{2}{|c|}{$\mathrm{Pb}$} & \multicolumn{2}{|c|}{$\mathrm{Ni}$} \\
\hline & $r$ & $p$-value & $r$ & $p$-value & $r$ & $p$-value \\
\hline $\mathrm{EC}(\mathrm{mS} / \mathrm{cm})$ & -0.119 & 0.778 & 0.490 & 0.217 & 0.414 & 0.308 \\
\hline $\mathrm{pH}$ & -0.493 & 0.214 & 0.002 & 0.996 & -0.546 & 0.161 \\
\hline Sand\% & -0.230 & 0.583 & -0.181 & 0.668 & -0.088 & 0.837 \\
\hline Silt\% & 0.157 & 0.711 & 0.037 & 0.930 & 0.092 & 0.828 \\
\hline Caly\% & 0.127 & 0.765 & 0.330 & 0.424 & -0.039 & 0.927 \\
\hline Cr Soil & 0.002 & 0.997 & -0.147 & 0.728 & -0.486 & 0.222 \\
\hline Pb Soil & 0.604 & 0.112 & $0.708^{*}$ & 0.049 & 0.659 & 0.075 \\
\hline Ni Soil & 0.124 & 0.769 & -0.160 & 0.705 & -0.284 & 0.496 \\
\hline
\end{tabular}

Table 4. The amount of heavy elements in the leaves of Conocarpus lancifolius sites, mean \pm SD $(n=2) *$ : Statistically significant at $p \leq$ 0.05 and LSD (5\%).

\begin{tabular}{lcccccc}
\hline Site & \multicolumn{3}{c}{ Soil (Mg/g d.wt) } & \multicolumn{3}{c}{ Plant (Mg/g d.wt) } \\
\cline { 2 - 6 } & \multicolumn{1}{c}{$\mathrm{Cr}$} & $\mathrm{Pb}$ & $\mathrm{Ni}$ & $\mathrm{Cr}$ & $\mathrm{Pb}$ & $\mathrm{Ni}$ \\
\cline { 2 - 6 } PR & $133.3^{\mathrm{a}} \pm 91.4$ & $128.8^{\mathrm{a}} \pm 115.0$ & $28.1^{\mathrm{bc}} \pm 0.61$ & $30.7^{\mathrm{a}} \pm 3.0$ & $20.4^{\mathrm{b}} \pm 1.7$ & $19.6^{\mathrm{a}} \pm 7.6$ \\
FR & $49.3^{\mathrm{ab}} \pm 3.7$ & $5.8^{\mathrm{a}} \pm 4.7$ & $21.6^{\mathrm{c}} \pm 1.8$ & $17.1^{\mathrm{bc}} \pm 2.1$ & $57.4^{\mathrm{a}} \pm 7.6$ & $9.1^{\mathrm{ab}} \pm 0.71$ \\
AMR & $96.0^{\mathrm{ab}} \pm 13.5$ & $1.5^{\mathrm{a}} \pm 1.7$ & $36.2^{\mathrm{a}} \pm 3.2$ & $24.6^{\mathrm{ab}} \pm 5.9$ & $15.2^{\mathrm{b}} \pm 11.0$ & $14.1^{\mathrm{ab}} \pm 47.7$ \\
KRB & $67.5^{\mathrm{ab}} \pm 1.6$ & $56.9^{\mathrm{a}} \pm 52.7$ & $31.5^{\mathrm{ab}} \pm 2.1$ & $15.3^{\mathrm{c}} \pm 1.8$ & $6.0^{\mathrm{b}} \pm 0.85$ & $8.3^{\mathrm{ab}} \pm 0.71$ \\
Control & $1.1^{\mathrm{b}} \pm 0.28$ & $0.27^{\mathrm{a}} \pm 0.01$ & $9.4^{\mathrm{d}} \pm 3.9$ & $9.2^{\mathrm{c}} \pm 0.57$ & $7.7^{\mathrm{b}} \pm 2.1$ & $6.5^{\mathrm{b}} \pm 4.38$ \\
(Non-polluted) & & & & & & \\
F & 2.882 & 1.935 & $31.913^{*}$ & $13.426^{*}$ & $23.395^{*}$ & 2.825 \\
P & 0.138 & 0.243 & $0.001^{*}$ & $0.007^{*}$ & $0.002^{*}$ & 0.142 \\
LSD (5\%) & 106.32 & 145.51 & 6.6826 & 8.3138 & 15.767 & 11.514 \\
\hline
\end{tabular}

Table 5. Ec, $\mathrm{pH}$ and proportions of soil particles to soil Conocarpus lancifolius sites, mean \pm SD $(n=2) *$ : Statistically significant at $\mathrm{p} \leq$ 0.05 and LSD (5\%).

\begin{tabular}{|c|c|c|c|c|c|}
\hline \multirow[t]{2}{*}{ Site } & \multirow[t]{2}{*}{$\mathrm{EC}(\mathrm{mS} / \mathrm{cm})$} & \multirow[t]{2}{*}{$\mathrm{pH}$} & \multicolumn{3}{|c|}{ Soil Texture\% } \\
\hline & & & Sand & Silt & Clay \\
\hline PR & $0.56^{b c} \pm 0.11$ & $7.59^{\mathrm{a}} \pm 0.10$ & $80.0^{c} \pm 0.0$ & $18.0^{\mathrm{ab}} \pm 0.0$ & $2.0^{b} \pm 0.0$ \\
\hline$F R$ & $0.65^{b} \pm 0.22$ & $7.63^{a} \pm 0.03$ & $85.0^{b} \pm 2.83$ & $13.0^{b} \pm 2.83$ & $2.0^{b} \pm 0.0$ \\
\hline AMR & $0.75^{b} \pm 0.04$ & $7.73^{a} \pm 0.14$ & $77.5^{c} \pm 0.71$ & $20.5^{a} \pm 0.71$ & $2.0^{b} \pm 0.0$ \\
\hline KRB & $1.44^{a} \pm 0.04$ & $7.64^{a} \pm 0.01$ & $77.0^{C} \pm 2.83$ & $20.0^{\mathrm{a}} \pm 4.24$ & $3.0^{\mathrm{ab}} \pm 1.41$ \\
\hline $\begin{array}{l}\text { Control } \\
\text { (Non-polluted) }\end{array}$ & $0.35^{c} \pm 0.01$ & $6.79^{b} \pm 0.04$ & $94.5^{a} \pm 0.71$ & $1.0^{c} \pm 0.0$ & $4.5^{\mathrm{a}} \pm 0.71$ \\
\hline $\mathrm{F}$ & $26.420^{*}$ & $47.237^{*}$ & $31.074^{*}$ & $24.811^{*}$ & 4.800 \\
\hline$P$ & $0.001^{*}$ & $<0.001^{*}$ & $0.001^{*}$ & $0.002^{*}$ & 0.058 \\
\hline LSD (5\%) & 0.2923 & 0.2058 & 4.7399 & 5.9179 & 1.8177 \\
\hline
\end{tabular}

Table 6. Correlation between Plant with different parameters of Conocarpus lancifolius sites, $r$ : Pearson coefficient *: Statistically significant at $p \leq 0.05(n=8)$.

\begin{tabular}{|c|c|c|c|c|c|c|}
\hline \multirow{3}{*}{ Parameter } & \multicolumn{6}{|c|}{ Plant (mg/g d.wt) } \\
\hline & \multicolumn{2}{|c|}{$\mathrm{Cr}$} & \multicolumn{2}{|c|}{$\mathrm{Pb}$} & \multicolumn{2}{|c|}{$\mathrm{Ni}$} \\
\hline & $r$ & $p$ & $r$ & $p$ & $r$ & $p$ \\
\hline $\mathrm{EC}(\mathrm{mS} / \mathrm{cm})$ & -0.601 & 0.115 & -0.570 & 0.140 & -0.578 & 0.134 \\
\hline $\mathrm{pH}$ & 0.187 & 0.658 & -0.024 & 0.954 & 0.302 & 0.467 \\
\hline Sand\% & -0.156 & 0.713 & $0.917^{*}$ & 0.001 & -0.086 & 0.840 \\
\hline Silt\% & 0.241 & 0.565 & $-0.848^{*}$ & 0.008 & 0.150 & 0.722 \\
\hline Caly\% & -0.450 & 0.263 & -0.363 & 0.376 & -0.340 & 0.410 \\
\hline Cr Soil & 0.534 & 0.172 & -0.277 & 0.507 & 0.233 & 0.579 \\
\hline PbSoil & 0.335 & 0.418 & -0.238 & 0.570 & 0.126 & 0.766 \\
\hline Ni Soil & 0.292 & 0.483 & $-0.766^{*}$ & 0.027 & 0.201 & 0.633 \\
\hline
\end{tabular}


Two plant species were chosen; Prosopis juli flora and Conocarpus lancifolius, which were collected from 4 sites. These plant species are shrubs or small trees. The sites include; (IF) near Iron Factory, (FR) King Faisal road, (JMR) Jeddah-Jazan road, and (SRB) North Sport Stadium Mohammed Al-Faisal branch road.

In addition, samples were taken from non-polluted sites from house in Alkhumrah, South Jeddah that were considered as control for the study. On the other hand, Conocarpus lancifolius, was collected from (PR) area near Petroleum Refinery, (FR) King Faisal road, (AMR) Alandalus road, and (KRB) ALQahirah branch roads. The selected sites were evaluated for their contamination status similar to a previous study conducted by Shirazi et al. (2006). Soil samples from different locations were collected and analyzed for different physio-chemical analysis. In addition, samples were collected from non-polluted sites (control) taken from house in Alkhumrah, South Jeddah. The samples of soil were taken from the same sites of the plant species.

\section{Analysis of soil and heavy metals in soil and plant samples}

The soil was collected from $(0-30) \mathrm{cm}$ below the surface and all soil samples were air dried. The dried samples were sieved through a $2 \mathrm{~mm}$ plastic sieve to remove large gravel-sized materials. Soil analyses included; soil texture, $\mathrm{pH}$ and EC. The Electrical conductivity (Ec) was obtained using a 1:5 soil water extract and electronic conductivity meter, following the procedure of Rhoades (1996). On the other hand, to determine heavy metals in soil, soil samples and air dried plant leaves were ground and subjected to microwave assisted digestion with $\mathrm{HNO}_{3}: \mathrm{H}_{2} \mathrm{SO}_{4}: \mathrm{HClO}_{4}$ mixture, an atomic absorption spectrophotometer. Moreover, Atomic Absortaption Spectrophotometer model Inductivity coupled with plasma emission spectrometer ICP (PARKIN ELEMER)) was used to determine the amount of $\mathrm{Cr}, \mathrm{Pb}$ and $\mathrm{Ni}$ following the method of Allen et al. (1974).

\section{Statistical analysis}

Data was fed into the computer and analyzed using IBM SPSS software package version 20.0 (Armonk, NY: IBM Corp). ANOVA was used for comparative analysis, Post Hoc test to carry out pair wise comparison and Spearman coefficient was used to carry out correlational analysis. The significance was found to be at $5 \%$ level of the obtained results.

\section{Conclusion}

Jeddah is a province with large number of population. However, there is a steady increase in the number of cars and number of factories due to industrialization in this region. The present study evaluated the phytoremediation by two plant species of Prosopis juli flora and Conocarpus lancifolius located in Jeddah, Saudi Arabia. Prosopis juli flora is a wild plant, which produces fruit edible by camel and sheep. However, due to the accumulation of heavy metals on the plant, it is dangerous for animals. On the other hand, Conocarpus lancifolius fruit is poisonous. The results showed that this plant can absorb a large amount of heavy metals especially lead, as compared to Prosopis juli flora. Growing plant species that can bear pollution and be able to clean up air are highly recommended. The quality of air depends on controlling the air pollution by controlling traffic and industrial activities. The study results have concluded that phytoremediation can be one of the best technologies that use living plants to clean up soil, air, and water contaminated with hazardous chemicals. However, the results are limited because the procedure was not replicated for confirming the obtained results. More studies are needed to obtain definite knowledge regarding effects on plant species due to accumulation of heavy metals.

\section{Acknowledgements}

The author is very thankful to all the associated personnel in any reference that contributed in/for the purpose of this research.

\section{References}

Agbogidi OM, Mariere AE, Ohwo OA (2013) Metal concentration in plant tissues of jatropha curcas L. grown in crude oil contaminated soil. J Sustain Forest. 32: 404-411.

Allen S, Grimashy HM, Parkinson JA, Armby C (1974) Chemical analysis of Ecological Materials. Oxford: Blackwell- Scientific Publications.

Alt DE, Kato N, Kramer U, Smith RD, Raskin I (2000) The role of root exudates in nickel hyper accumulation and tolerance in accumulator and non-accumulator species of Thlaspi. In: Phytoremediation of contaminated soil and water (TERRY N., BANUELOS G.). London: CRC Press LLC.

Aslam M, Verma DK, Dhakerya R, Rais S, Alam M, Ansari FA (2012) Bio indicator: a comparative study on uptake and accumulation of heavy metals in some plant's leaves of m.g. road, Agra city, India. Res J Environ Earth Sci. 4: 1060-1070.

Butkus D, Baltrènaitè E (2007) Transport of heavy metals from soil to Pinus sylvestris L. and betula pendula trees. J Ecol. 53: 29-36.

Chiroma TM, Ebewele RO, Hymore FK (2014) Comparative assessment of heavy metal levels in soil, vegetables and urban grey waste water used for irrigation in Yola and Kano. Int Ref J Eng Sci. 3: 2319-1821.

Gomes MP, Marques TC, e Melo S, Nogueira MD, Castro EM, Soares ÂM (2011) Ecophysiological and anatomical changes due to uptake and accumulation of heavy metal in Brachiaria decumbens. Scientia Agricola. 68: 566-573.

Gupta S, Chakrabarti SK (2013) Effect of heavy metals on different anatomical structures of Bruguiera sexangula. Int J Bio-Res Stress Manage. 4.

Kabata-Pendias A. 2010. Trace elements in soils and plants. CRC press.

Khan MJ, Jan MT, Farhatullah NU, Khan MA, Perveen S, Alam S, Jan AU (2011) The effect of using waste water for tomato. Pak J Bot. 43: 1033-1044. 
Lübben S, Sauerbeck D (1991) The uptake and distribution of heavy metals by spring wheat. Water Air Soil Pollut. 57: 239247.

Markert B (1993) Plant as biomonitors. Indicators for heavy metals in the terrestrial environment. (Markert B Ed.) Vch Weinheim, New York. 281-304.

Morsy AA, Salama A, Hamid K, Kamel HA, Fahim Mansour MM (2012) Effect of heavy metals on plasma membrane lipids and antioxidant enzymes of Zygophyllum species. Eurasia J Biosci. 6.

Naser HM, Sultana S, Mahmud NU, Gomes R, Noor S (2011) Heavy metal levels in vegetables with growth stage and plant species variations. Bangladesh J Agric Res. 36: 563-574.

Nazir R, Khan M, Masab M, Rehman HU, Rauf NU, Shahab S, Ameer N, Sajed M, Ullah M, Rafeeq M, Shaheen Z (2015) Accumulation of heavy metals ( $\mathrm{Ni}, \mathrm{Cu}, \mathrm{Cd}, \mathrm{Cr}, \mathrm{Pb}, \mathrm{Zn}, \mathrm{Fe}$ ) in the soil, water and plants and analysis of physico-chemical parameters of soil and water collected from Tanda Dam Kohat. J Pharm Sci Res. 7: 89.
Osma E, Serin M, Leblebici Z, Aksoy A (2013) Assessment of heavy metal accumulations $(\mathrm{Cd}, \mathrm{Cr}, \mathrm{Cu}, \mathrm{Ni}, \mathrm{Pb}$, and $\mathrm{Zn})$ in vegetables and soils. Pol J Environ Stud. 22.

Rhoades JD (1996) Salinity: Electrical conductivity and total dissolved solids. Methods of Soil Analysis Part 3-Chemical Methods. 417-435.

Salt DE, Smith RD, Raskin L (1998) Phytoremediation. Ann Rev Plant Phys Plant Mol Biol. 49: 643-668.

Samara C, Voutsa D (2005) Size distribution of airborne particulate matter and associated heavy metals in the roadside environment. Chemosphere. 59: 1197-1206.

Shaheen MA, El-Nakhlawy FS, Almehmadi FM, Al-Shareef AR (2013) Heavy metals contents in Ziziphus tree leaves under the effect of different industrial activities. J Agric Sci. 6: 110.

Shirazi MU, Khan MA, Ali M, Mujtaba SM, Mumtaz S, Ali M, Jafri KA (2006) Growth performance and nutrient contents of some salt tolerant multipurpose tree species growing under saline environment. Pak J Bot. 38: 1381-1388. 